\title{
フライアッシュコンクリートの空気連行性・気泡組織と耐凍害性 AIR ENTRAINING, AIR VOID SYSTEM AND FROST DURABILITY OF FLY ASH CONCRETE
}

\author{
千歩 修*, 浜 幸 雄** \\ Osamu SENBU and Yukio HAMA
}

\begin{abstract}
Control of air content and resistance to frost damage are essential for fly ash concrete. This paper demonstrates a possibility of controlling the air content of fly ash concrete by the basic properties of fly ash. It also elucidates the tendencies of the effects of the presence of fly ash, mixing conditions, and type of air-entraining admixture on the air content, air void system, and air loss by agitation. The frost resistance test results of fly ash concrete slightly lower than normal concrete are found attributable to the fact that its air-void spacing factor is larger than normal concrete and that the initial curing time of 2 weeks specified for freezing and thawing testing is insufficient for fly ash concrete.
\end{abstract}

Keywords: fly ash, frost durability, spacing factor, air entraining

フライアッシュ、酎凍害性、気泡間隔係数、空気連行性

1. はじめに

フライアッシュは有用な混和材であるが、フライアッシュをコン クリートに混和材として使用すると、フライアッシュに含まれる未 燃炭素が $\mathrm{AE}$ 剂を吸着し、所要の空気量を得るための $\mathrm{AE}$ 剂量が普 通コンクリートに比べて多量となり、空気量の経時変化も大きくな るりといわれている。また、フライアッシュ自体の品質も変動するた め、フライアッシュを使用したコンクリートの空気量の管理は難し いものとなっている。さらに、フライアッシュコンクリートは、普 通コンクリートに比べて耐凍害性に劣るとの報告 ${ }^{2)}$ もあり、この理 由として気泡組織が普通コンクリートと異なること、強度增進が遅 いために養生が不十分な状態で凍結融解試験を開始していること等 が考えられる。

本研究では、まず、品質の変動するフライアッシュに対して所要 の空気量を確保する方法として、フライアッシュの品質から所要の 空気量を得るために必要 $\mathrm{AE}$ 椷量を算定する方法3) が空気量の管理 に利用できるかを検討した。さらに、 $\mathrm{AE}$ 郕種別、ミキサー種別、ア ジテート・静置等の条件が、この算定方法(すなわち、フライアッ シュの品質をとらえ所定の空気量を得るための $\mathrm{AE}$ 凪量を算定する 方法)さらには気泡組織におよぼす影響を明らかにした。次に、 $\mathrm{AE}$ 片種別およびミキサー種別が気泡組織に及ぼす影響、さらには養生 期間がコンクリートの耐凍害性に及ぼす影響について検討した。

\section{2. 実験の概要}

本研究は以下の 3 つのリーズからなり、それぞれのシリーズの 実験計画を表 1 表 3 に示す。

シリーズ1(表 1) は、フライアッシュの品質変動と空気量管理手法 を検討するものである。ここでは、まず、4 種類の炭種のフライアッ シュをそれぞれ数回、採取し、その品質変動をとらえる。次に、そ れぞれのフライアッシュの品質 (ここでは、電源開発 (株) 仕様書 (案) によるメチレンブルー吸着量)から以下に示す $\mathrm{AE}$ 剂量推定式3) で空 気量が $4 \%$ となる $\mathrm{AE}$ 鼡量を算出し、この $\mathrm{AE}$ 剂量で混練した。なお、 このときの係数 $\mathrm{b}$ は既往の文献3) の值を用いた。

$\mathrm{A}=(\mathrm{C}+\alpha \mathrm{F}) \times \mathrm{a} / 100$ $\cdots(1)$

ここに、 $\alpha=\mathrm{bQ} \quad \mathrm{A}$ ：単位 $\mathrm{AE}$ 郕量 $\left(\mathrm{kg} / \mathrm{m}^{3}\right)$

C: 単位セメント量 $\left(\mathrm{kg} / \mathrm{m}^{3}\right) \quad \mathrm{F}$ : 単位フライアッシュ量 $\left(\mathrm{kg} / \mathrm{m}^{3}\right)$ $\alpha \mathrm{F}$ : フライアッシュの等価単位セメント量 $\left(\mathrm{kg} / \mathrm{m}^{3}\right)$

$\mathrm{a}$ : 普通コンクリートの $\mathrm{AE}$ 剂使用量（\%）

$\mathrm{Q}$ : フライアッシュの特性値から定まる定数（メチレンブルー吸着量） $\mathrm{b}: \mathrm{AE}$ 剂の種類と $\mathrm{Q}$ との組み合わせで決まる係数

ここでは、実際には空気量が $4 \%$ とはならなかったため、さらに 4 \%をはさむような $\mathrm{AE}$ 剂量で混練を行い、今回の実験デー夕におけ る空気量が $4 \%$ となる $\mathrm{AE}$ 㓮量・係数 $\mathrm{b}$ の算定および空気量管理手法 の検討を行った。

* 北海道大学大学院工学研究科材料性能学研究室 助教授・ 工博

** 室蘭工業大学工学部 助教授・博士 (工学)
Assoc. Prof., Div. Building Materials, Graduate School of Hokkaido Univ.; Dr. Eng. Assoc. Prof., Faculty of Engineering, Muroran Institute of Technology, Dr. Eng. 
シリーズ2（表 2) は、混練・アジテート等の条件が空気量・気泡 組織に及ぼす影響を検討するものである。 5 種類のミキサー（強制鄮 汼 $50 \ell$ ミキサー、傾胴型ミキサー、水平 2 軸強制練りミキサー、強

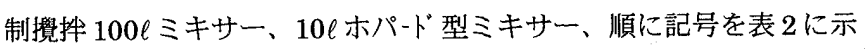
す。以下、記号で表記。また、 50 強制で練量が半分のものは $25 / 50$ 強制と表記)を用い、練量・フライアッシュの有無・ $\mathrm{AE}$ 剂種類を組み 合わせ、練上がり時、静置およびアジテート後の空気量、気泡組織 を検討した。実験は、練上がり時の測定をした後、残りのコンクリー トをアジテート用と静置用に分けて経時変化の測定用とした。その 後、アジテート用、静置用とも 20 分おきに 60 分までモールドを用 いた質量法で JIS A 1116 に準じて空気量を測定した。なお、この試 験体は、硬化後、リニア・トラバース法の測定用とした。練量の少 ない $25 / 50$ 強制と 10 ホパは、練上がり時と 60 分後のみ測定を行い、 基本となる 50 強制については、経時変化に伴う気泡組織の変化も測 定した。

シリーズ 3 (表 3) は、耐凍害性におよぼす各種の要因の影響を検 討したものである。ここでは、 $\mathrm{AE}$ 剂種類、ミキサーの種類（強制、 傾胴)、アジテートによる経時変化、試験開始材齢の影響を検討した。 試験開始材齢は、一般的な凍結融解試験の条件である 2 週の他に、置 換率が $15 \%$ のフライアッシュコンクリートが普通コンクリートと同 等の圧縮強度となる 4 週のもの、および水結合材比を $45 \%$ とするも のを加えた。

\section{3. 使用材料および実験方法}

各シリーズに共通する材料として、 $\mathrm{AE}$ 剂はフライアッシュ用と一 般用を使用し、その概要を表 4 に示す。セメントは、普通ポルトラ ンドセメント (密度 $3.16 \mathrm{~g} / \mathrm{cm}^{3}$ )、骨材は、細骨材に勇払産陸砂（表 乾比重 2.65)、粗骨材に常盤産砗石（表乾比重 2.62）を使用した。ま た、シリーズ 2,3 で使用したフライアッシュの性状を表 5 に示す。な お、調合種別の表示が必要な場合、フライアッシュの有無と $\mathrm{AE}$ 剂 種別を組み合わせて表示する(例:WA1)。

各シリーズの基本調合を表 6 に示す。シリーズ 1 では、普通コン クリートでスランプ $18 \pm 1 \mathrm{~cm}$ 、空気量 $4 \pm 1 \%$ となるように調合を 決定し、結合材質量の $20 \%$ をフライアッシュに置き換えたものを基 本調合とした。な拉、AE剤量は(1) 式により決定した。シリーズ 2,3 では、フライアッシュの置換率を $15 \%$ とし、フライアッシュの有無・ $\mathrm{AE}$ 剂種別・目標空気量ごとに、50 強制を用いた試練りでスランプ $18 \pm 1 \mathrm{~cm}$ を目標に決定し、ミキサーによらず同調合で混練した。

各シリーズとも、混練は材料を一括投入し、混練時間は各ミキ サーの通常の混練時間 (ミキサー種別によらず 3 分間) とした。練上 がり時には、練温、スランプ（JS A 1101）、モールドを用いた質量 法による空気量（ЛS A 1116 に準ずる）の測定を行い、練温は $25 \pm$ $1{ }^{\circ} \mathrm{C}$ とた。また、シリーズ 2 および 3 では、質量法（JS A 1116）お よび圧力法（JIS A 1128）により空気量も測定した。アジテートは、 傾胴型ミキサーによって行い、1 分間に 4 回の割合で回転を与えた。

シリーズ 3 の一部では、圧縮強度試験 (JIS A 1108)、引張強度試 験 (JS A 1113)を、それぞれ材齢 2 週、4 週で測定した。シリーズ 3 の凍結融解試験については、ASTM C 666 A 法に準じて 300 サイク ルまで測定し、シリーズ 2,3 の気泡組織は、リニア・トラバース法 （ASTM C 457）に準じて測定を行った。
表 1 実験計画（沙-ス¹）

\begin{tabular}{|c|c|c|c|c|}
\hline \multicolumn{2}{|c|}{ フライアッシュ種類 } & \multirow[b]{2}{*}{ 基礎性状試験 } & \multirow{2}{*}{ AE剂 } & \multirow{2}{*}{ AE斉量 } \\
\hline 炭種 & 採取条件 & & & \\
\hline 南屯(南屯) & 5種類 & 比重 ～～～ & & ·目標空気量4\% \\
\hline ワンボー(WA) & 11 種類 & 強熱減量 & （記号:M） & ((1)式による) \\
\hline ドレートン(DR) & 1種類 & 妖ンブルー吸着量 & 一般用 & -実験結果に応じ \\
\hline オプテ仅 (OP & 1種類 & ブレー值 & （記号:A1） & て設定 \\
\hline
\end{tabular}

表 2 実験計画（沙-ズ 2)

\begin{tabular}{|c|c|c|c|c|c|c|c|}
\hline \multirow{2}{*}{$\begin{array}{c}\text { ミキサー種類 } \\
\text { (記号) }\end{array}$} & \multirow[b]{2}{*}{ 練量 } & \multirow{2}{*}{ FA有無 } & \multirow[b]{2}{*}{$A E n_{n}$} & \multicolumn{4}{|c|}{ 空気童等の測定 } \\
\hline & & & & 0分 & 20分 & 40分 & 60分 \\
\hline \multirow{2}{*}{50 強制 } & 50 & \multirow{6}{*}{$\begin{array}{c}\text { なし } \\
\text { (記号:0) } \\
\text { あり } \\
\text { (記号:W) }\end{array}$} & \multirow{3}{*}{ M } & $\triangle \triangle \square$ & $\triangle \square$ & $\Delta \square$ & $\Delta \square$ \\
\hline & 25 & & & $\Delta \triangle \square$ & - & - & $\Delta \square$ \\
\hline 傾胴 & 50 & & & $O \Delta \square$ & $\Delta$ & $\Delta$ & $\Delta \square$ \\
\hline 水平2䡩 & 50 & & \multirow{3}{*}{ A1 } & $\Delta \triangle \square$ & $\Delta$ & $\Delta$ & $\Delta \bar{\square}$ \\
\hline 100 強制 & 50 & & & $\Delta \square$ & $\Delta$ & $\triangle$ & $\Delta \square$ \\
\hline 10 木ハ & 10 & & & $\Delta \square$ & - & - & $\Delta \square$ \\
\hline
\end{tabular}

表 3 実験計画（シリーズ3）

\begin{tabular}{|c|c|c|c|c|c|c|c|c|}
\hline W/B & FA有無 & AE斉 & ミキサー & Air $(\%)$ & 材齢苓 & 凍結融解 & 気泡組織 & 強度 \\
\hline \multirow{10}{*}{$55 \%$} & \multirow{5}{*}{0} & \multirow{6}{*}{$M$} & \multirow{6}{*}{ 強制 } & \multirow{2}{*}{$3 \%$} & $2 W$ & 0 & 0 & 0 \\
\hline & & & & & $4 W$ & $x$ & 0 & 0 \\
\hline & & & & \multirow{2}{*}{$4 \%$} & $2 W$ & 00 & 00 & 00 \\
\hline & & & & & $4 W$ & (O) & 0 & (O) \\
\hline & & & & \multirow{2}{*}{$5 \%$} & $2 W$ & $\mathrm{O}(\mathbf{0})$ & $\mathrm{O}(\mathbf{0})$ & $\mathrm{O}(0$ \\
\hline & \multirow[t]{5}{*}{ W } & & & & $4 \mathrm{~W}$ & $x$ & 0 & 0 \\
\hline & & \multirow{4}{*}{ A1 } & \multirow{4}{*}{ 傾胴 } & \multirow{2}{*}{$4 \%$} & $2 W$ & $\mathrm{O}[\mathrm{O}]$ & $O[0]$ & $0[0$ \\
\hline & & & & & $4 \mathrm{~W}$ & $x$ & 0 & (O) \\
\hline & & & & \multirow{2}{*}{$\mathrm{A} 4 \%{ }^{*}{ }^{* 1}$} & $2 W$ & 0 & 0 & 00 \\
\hline & & & & & $4 W$ & $x$ & 0 & $x$ \\
\hline
\end{tabular}

注） ※1 A4\%はアジテート後4\%を目標とした $○$ : 練上がり後、試験体作製 $※ 2$ 凍結融解開始·強度試験の材齢 (): FA有のみ

[]:FA有·AE剂Mのみ

表 $4 \mathrm{AE}$ 剤の概要

\begin{tabular}{|c|c|c|}
\hline 記号 & 種類 & 主成分 \\
\hline M & フライアッシュ用特殊AE刘 & $\begin{array}{c}\text { 高アルキルカルポ酸系陰仏ン界面活性剤 } \\
\text { と非仏界面活性剂 }\end{array}$ \\
\hline A1 & 一般用AE刘 & アルキルエーテル型陰仏ン界面活性剤 \\
\hline
\end{tabular}

表 5 フライアッシュの基礎性状（シリーズ 2,3）

\begin{tabular}{|c|c|c|c|c|c|}
\hline 炭種 & $\begin{array}{c}\text { 湿分 } \\
(\%)\end{array}$ & $\begin{array}{c}\text { 強熱減量 } \\
(\%)\end{array}$ & $\begin{array}{c}\text { 密度 } \\
\left(\mathrm{g} / \mathrm{cm}^{3}\right)\end{array}$ & $\begin{array}{c}\text { ブレーン值 } \\
\left(\mathrm{cm}^{2} / \mathrm{g}\right)\end{array}$ & $\begin{array}{c}\text { ×チンブルー吸着量 } \\
(\mathrm{mg} / \mathrm{g})\end{array}$ \\
\hline ワンボー & 0.22 & 2.7 & 2.16 & 3754 & 0.88 \\
\hline
\end{tabular}

\section{表 6 基本調合}

\begin{tabular}{|c|c|c|c|c|c|c|c|c|c|c|}
\hline \multirow[t]{2}{*}{ 沙 $-\lambda^{*}$} & \multirow{2}{*}{$\begin{array}{l}\text { 目標 } \\
\text { Air }\end{array}$} & \multirow{2}{*}{$\begin{array}{c}\text { W/B } \\
(\%)\end{array}$} & \multirow{2}{*}{$\begin{array}{l}\text { S/A } \\
(\%)\end{array}$} & \multirow{2}{*}{$\begin{array}{c}\text { 単位水量 } \\
\left(\mathrm{kg} / \mathrm{m}^{3}\right)\end{array}$} & \multicolumn{4}{|c|}{ 質量 $\left(\mathrm{kg} / \mathrm{m}^{3}\right)$} & \multicolumn{2}{|c|}{ AE剂量(\%) } \\
\hline & & & & & セxง & FA & 細骨材 & 粗骨材 & $M$ & $\mathrm{Al}$ \\
\hline 1 & $4 \%$ & 55 & 46.8 & 168 & 248 & 62 & 851 & 993 & - & - \\
\hline \multirow{2}{*}{2} & $4 \%$ & 55 & 48.4 & 173 & 315 & 0 & 894 & 955 & 0.015 & 0.003 \\
\hline & $4 \%$ & 55 & 47.8 & 173 & 267 & 47 & 876 & 955 & 0.042 & 0.019 \\
\hline \multirow{8}{*}{3} & $3 \%$ & 55 & 49.1 & 173 & 315 & 0 & 921 & 955 & 0.004 & 0.001 \\
\hline & $4 \%$ & 55 & 48.4 & 173 & 315 & 0 & 894 & 955 & 0.011 & 0.002 \\
\hline & $\mathrm{A} 4 \%$ & 55 & 48.4 & 173 & 315 & 0 & 894 & 955 & 0.024 & 0.005 \\
\hline & $5 \%$ & 55 & 47.6 & 173 & 315 & 0 & 867 & 955 & 0.021 & 0.004 \\
\hline & $3 \%$ & 55 & 48.6 & 173 & 267 & 47 & 903 & 955 & 0.031 & 0.013 \\
\hline & $4 \%$ & 55 & 47.8 & 173 & 267 & 47 & 876 & 955 & 0.048 & 0.017 \\
\hline & $\mathrm{A} 4 \%$ & 55 & 47.8 & 173 & 267 & 47 & 876 & 955 & 0.056 & 0.025 \\
\hline & $5 \%$ & 55 & 47.1 & 173 & 267 & 47 & 849 & 955 & 0.060 & 0.020 \\
\hline
\end{tabular}




\section{4. 実験結果および考察}

4.1 フライアッシュの品質変動と空気量管理手法の検討

フライアッシュの採取日とメチレンブル一吸着量、連行空気量の 関係を図 1 に示す。同じ炭種でも採取日によってメチレンブルー吸 着量の值に変動が見られる。空気量で黒塗りのものは、（1）式に文 献 2) のb 值 (M:1.80, A1:70.63) を用いて目標空気量 4\%で混練した ものである。全体に空気量が多く、メチレンブルー吸着量が同等の ものでも空気量に違いが出ている。同図の白抜きのものは、本実験 のデータで算定した b 值 $(\mathrm{M}: 1.18, \mathrm{A1}: 33.64)$ を用いて求めた空気量が $4 \%$ となる時の $\mathrm{AE}$ 剂量で混練した場合の実際の空気量である。やや ばらつきはあるものの、 $4 \%$ に近い值となっており、適切に $\mathrm{b}$ 值を設 定することにより（1）式を空気量の管理に活用できる可能性がある ことがわかる。また、フライアッシュの採取年度により $\mathrm{b}$ 值が異なっ ており、メチレンブルー吸着量が測定者の比色による判定のために ばらつきが生じているか、あるいはメチレンブルー吸着量だけでは 表現できない要因が必要 $\mathrm{AE}$ 剂量に影響しているものと考えられる。

\section{2 混練条件が空気量、気泡組織に及ぼす影響}

（1）ミキサー種別による空気連行性

各ミキサーの練上がり時の空気量を図 2 に示す。この図からミキ サーには空気が入りやすいものがあり、しかも調合種別の影響は小 さいことがわかる。特に、傾胴は空気が入りやすくなっている。ま た、練り量の異なる 50 強制と $25 / 50$ 強制を比較すると、 $25 / 50$ 強制 の空気量が少なくなっている。

ここで、空気量におよぼすミキサーの影響は明確な傾向があり、 （1）式にミキサーの影響を加えることを検討する。ミキサ一の影響 は、コンクリートの種類によらず、ミキサーの種類・練り量による 影響のみであると仮定すると、（1）式は、以下のように書きかえら れる。

$$
\mathrm{A}=(\mathrm{C}+\alpha \mathrm{F}) \times \mathrm{aa}^{\prime} / 100
$$

ここに、 $\mathrm{a}^{\prime}:$ ミキサーの種類・練り量により定まる定数

練上がり時の空気量を用い、10 ホパ（(1) 式を導いた時の実験で 用いたミキサー）の $\mathrm{a}^{\prime}$ 值を 1 とした場合に、他のミキサーの $\mathrm{a}^{\prime}$ 值は、 表 7 のように表される。図 3 に、空気量が $4 \%$ となるときの $\mathrm{AE}$ 剂量 の計算值（(1) 式および (2) 式で計算) と実験值の関係を示す。なお、 ここで、 $\mathrm{a}^{\prime}$ 值は表 7 の平均值を用いている。この図から（2）式によ り計算することにより、空気量におよぼすミキサーの効果を表現で きると考えられる。

\section{(2) 空気量の経時変化}

練上がり時と 60 分後の空気量をアジテートと静置に分けて図 4 に 示す。アジテートしたものの方が静置したものより空気量の低下が 大きくなっているが、各調合の空気量の低下傾向は同様となってい る。各調合を比較すると、 $\mathrm{AE}$ 剂 $\mathrm{A} 1$ を用いたもの、フライアッシュ を用いたものの空気量の低下が大きくなっている。また、フライ アッシュを混入し、アジテートしたものの空気量は、AE 用 Mにおい ても低下が大きくなっている。

アジテート中の空気量の変化をミキサーごとに表したものを図 5 に示す。混練に水平 2 軸または傾胴を用いたものは、アジテート後 20 分までに空気量が低下し、特に、フライアッシュを用いたものの 場合は急激に低下している。一方、50 強制、100 強制では、急激な

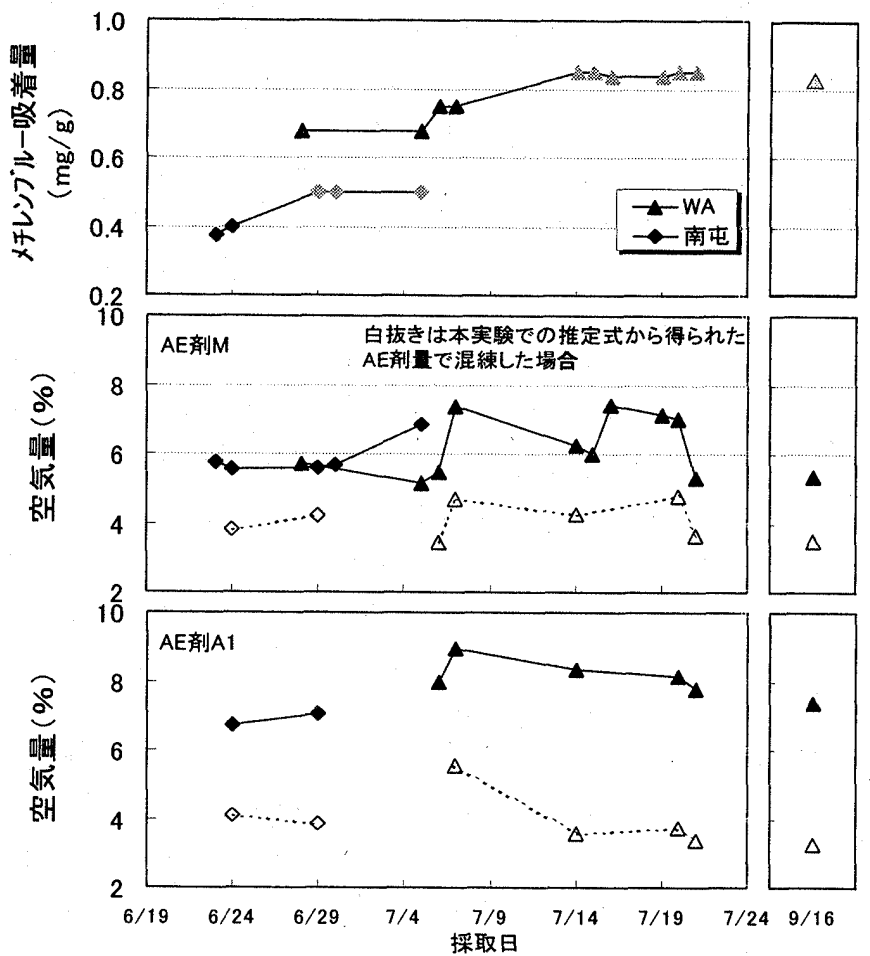

図 1 フライアッシュの品質変動と連行空気量

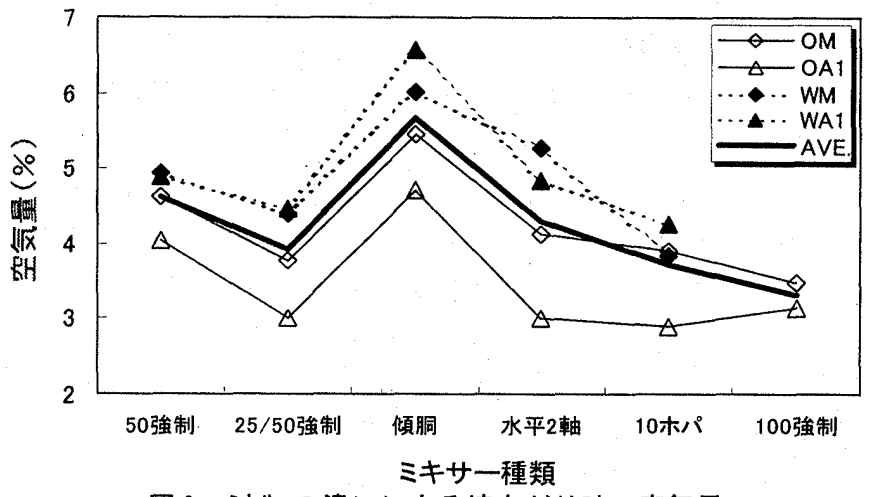

図 2 ミキサーの違いによる練上がり時の空気量

表 7 今回の実験結果から得られた a' 值

\begin{tabular}{|c|c|c|c|c|c|c|}
\hline & 50 強制 & $25 / 50$ 強制 & 傾胴 & 水平2軸 & 10 ホパ & 100 強制 \\
\hline OM & 0.85 & 1.04 & 0.72 & 0.95 & 1.00 & 1.12 \\
\hline OA1 & 0.89 & 1.15 & 0.73 & 0.83 & 1.00 & - \\
\hline WM & 0.72 & 0.96 & 0.61 & 0.96 & 1.00 & 0.92 \\
\hline WA1 & 0.91 & 1.05 & 0.68 & 0.92 & 1.00 & - \\
\hline AVE. & 0.84 & 1.05 & 0.69 & 0.92 & 1.00 & 1.02 \\
\hline
\end{tabular}

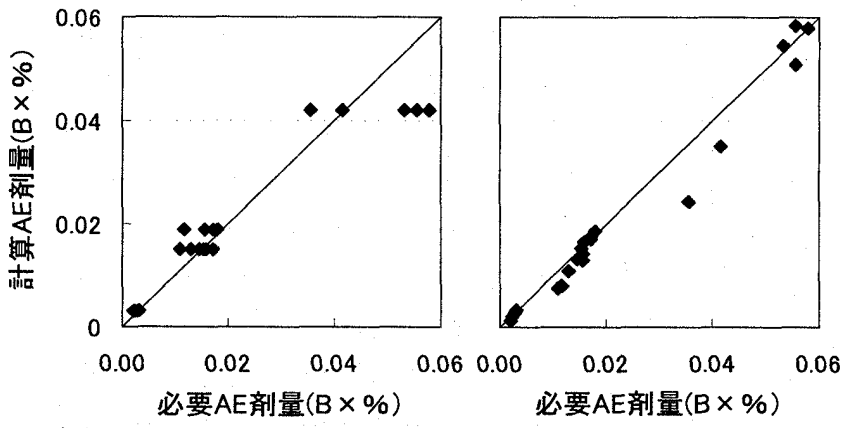

（1）式により計算した場合（2）式により計算した場合

図 3 単位 AE 都量の実験值と計算値の関係（空気量 4\%) 
空気量の低下は認められず、 $\mathrm{AE}$ 剂 $\mathrm{M}$ を用いたものでは、 20 分後に 空気量が增加している。このような経時変化の違いは、混練時のミ キサ一の特性による気泡組織の違いを表しているものと考えられる。

60 分後の空気量の変化をミキサーごとに比較したものを図 6 に示 す。アジテートと静置を比較すると、25/50 強制を用いたもの以外は アジテートした方が空気量の低下が大きく、全てのミキサーで $\mathrm{AE}$ 剤 $\mathrm{A} 1$ の方が $\mathrm{AE}$ 剂 $\mathrm{M}$ より空気量の低下が大きくなっている。

参考に、フライアッシュ用 $\mathrm{AE}$ 剂の品質基準值 ${ }^{4)}$ を図中に示す。な お、この基準では使用するフライアッシュの品質が制限され、強熱 減量の值を $1 \mathrm{~m}^{3}$ 中に $4.80 \mathrm{~kg}$ として 60 分静置後に評価を行うもので ある。今回の実験では強熱減量の值は $1.27 \mathrm{~kg}$ となっているが、この 基準值と比較すると、 $\mathrm{AE}$ 剂 $\mathrm{A} 1$ を用いたものは 10 ホパ以外の全て のミキサーでこの基準值よりも静置後の空気量の低下が大きくなっ ている。また、 $\mathrm{AE}$ 用 $\mathrm{M}$ を用いたものは、静置した場合、全てのミ キサーで基準值よりも空気量の低下が小さいが、アジテートすると 基準值よりも大きくなるものがある。ミキサーでは、水平 2 軸、傾 胴を用いたものをアジテートしたときの空気量の低下が大きくなっ ている。このため、フライアッシュ用 $\mathrm{AE}$ 荗を評価する場合、混練 条件、アジテートと静置の違いについても考慮する必要があるもの と思われる。

\section{（3）気泡組織}

練上がり時に採取したコンクリートの硬化後の気泡間隔係数をミ キサーごとに比較したものを図 7 に示す。練り量の少ない 10 ホパ、 50 強制を用いて練り量を半分とした $25 / 50$ 強制の気泡間陑係数が大 きくなっており、これは練り量の影響であると考えられる。他のミ キサーでは、コンクリートの種類による違いはあるが、水平 2 軸で やや小さくなる程度で、ミキサーによる気泡間隔係数の違いはそれ ほど大きくなっていない。しかしながら、ミキサーが翼なると空気 量が異なり、空気量が大きくなると気泡間隔倸数が大きくなり、こ の影響が含まれているものと考えられる。このため、傾胴では気泡 間隔係数が小さくなっているが、空気量の大きさを考えると、粗大 な空気泡が混入されているものと思われる。

コンクリートの種類で比較すると、 $\mathrm{AE}$ 剂 $\mathrm{M}$ を用いたものの気泡 間隔係数が小さく、特に、WA1 とWM は同程度の空気量であるに もかかわらず、気泡間隔係数に大きな違いが出ている。また、 $\mathrm{AE}$ 剂 $\mathrm{A} 1$ を用いたものでは、フライアッシュコンクリートの方が気泡間隔 係数が大きくなっているが、 $\mathrm{M}$ を用いたものではフライアッシュコ ンクリートの方が気泡間隔係数が小さくなっている。このため、フ ライアッシュコンクリートの場合には空気量だけでなく、気泡組織 に注意して $\mathrm{AE}$ 剂を選定する必要があるものと思われる。

練上がり時に採取したコンクリートと 60 分経過後に採取したコン クリートの硬化後の気泡間隔係数を比較したものをアジテート後と 静置後に分けて図8に示す。普通コンクリートは、アジテートによつ て気泡間隔係数がやや小さくなる傾向がある。しかしながら、フラ イアッシュコンクリートの気泡間隔係数は逆に大きくなる傾向があ り、特に、フライアッシュコンクリートに一般用の $\mathrm{AE}$ 羭を用いたも のの気泡間隔係数が大きくなることがわかる。また、気泡間隔係数 の小さいコンクリートはアジテート後も気泡間隔係数の変化は小さ く、実際の施工を考えると気泡間隔係数の小さいコンクリートとす る必要があるものと考えられる。静置した場合では、気泡間隔係数

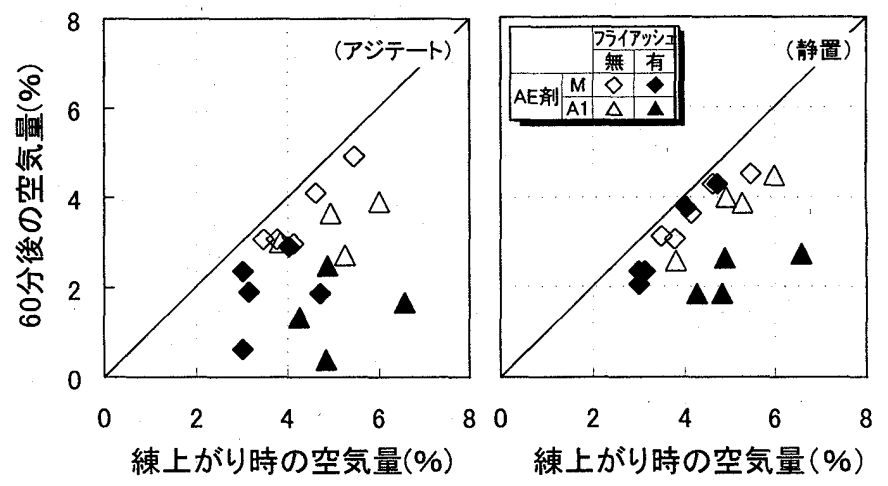

図 4 練上がり時と 60 分後の空気量
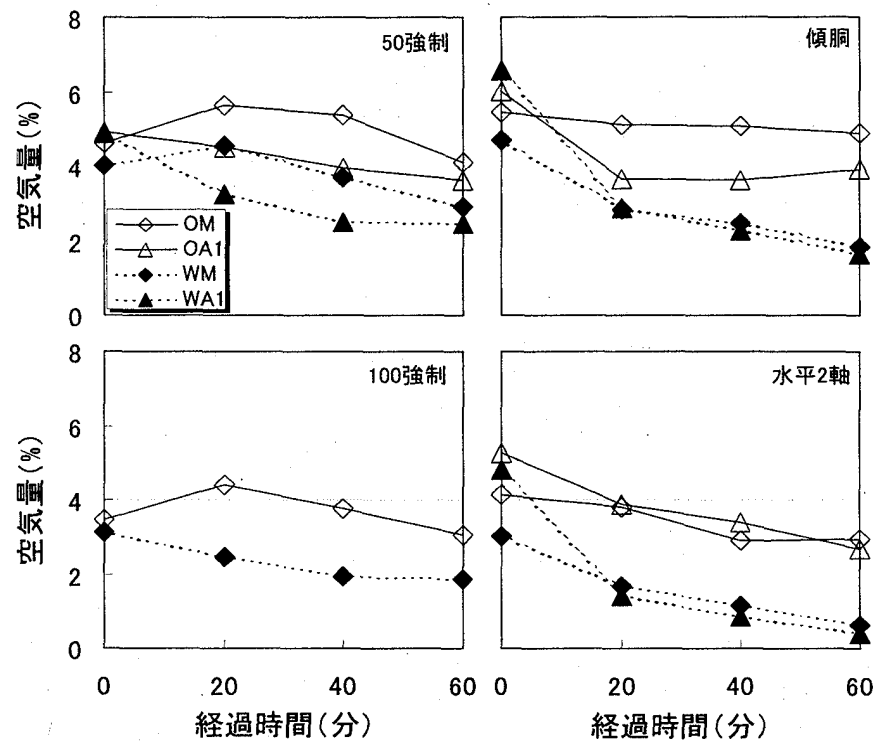

図 5 アジテート中の空気量の変化

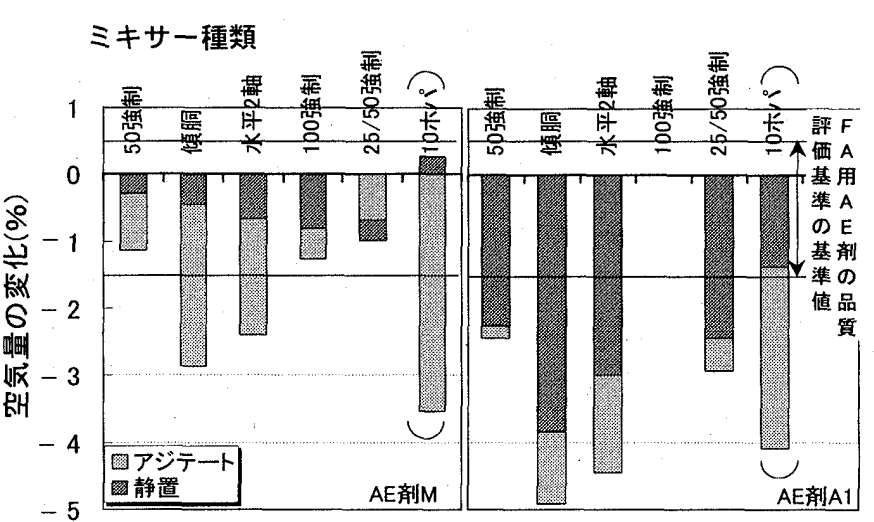

図 6 練上がり時と 60 分後の空気量

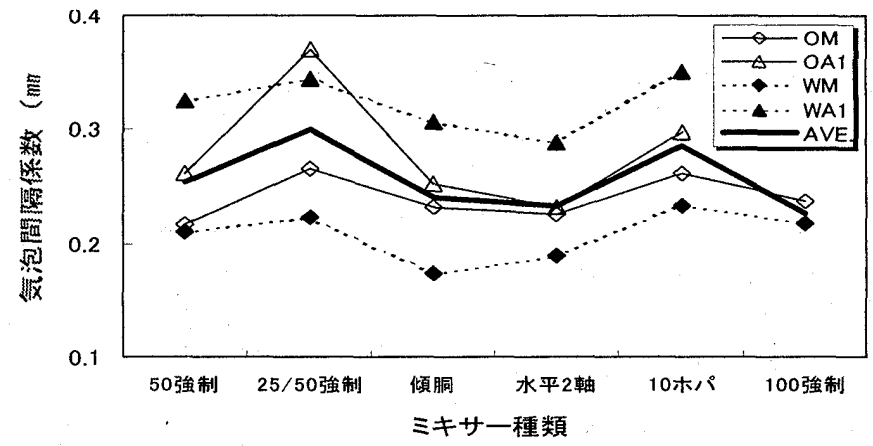

図 7 ミキサーの種類が気泡間隔係数に及ぼす影響 
の変化は小さいが、アジテートした場合と同様の傾向が表われてい るものと考えられる。

\section{3 耐凍害性に与える影響要因の検討 \\ （1）耐凍害性に及ぼす空気量の影響}

打込み時の空気量と凍結融解試験開始条件を水中養生 2 週とした 試験体の耐久性指数および 300 サイクルにおける質量減少率の関係 を図 9 に示す。なお、図にはアジテート後および静置後のコンクリー トも含まれている。空気量と耐久性指数の関係をみると、空気量が 少なくても耐久性指数が高いもの、空気量が多くても耐久性指数の 小さいものがあり、打込み時の空気量だけでは耐久性指数を説明で きないことがわかる。コンクリート種別で比較すると、フライアッ シュコンクリートの耐久性指数が低く、特に、 $\mathrm{AE}$ 剂 $\mathrm{A} 1$ を用いたフ ライアッシュコンクリートの耐久性指数が低くなっている。また、 フライアッシュコンクリートは普通コンクリートよりも質量減少率 が大きい傾向があり、特に、AE 剂 $\mathrm{A} 1$ を用いたものの質量減少率が 大きくなっている。しかしながら、 $\mathrm{AE}$ 鼡 $\mathrm{M}$ を用いると、普通コン クリートとフライアッシュコンクリートの質量減少率の差は小さく なっている。

（2）耐凍害性に及ぼすミキサー種別・アジテートの影響

ミキサー種別・アジテートが硬化後の空気量と酎久性指数に及ぼ す影響を図 10 に示す。アジテートを行わないものでミキサー種別の 影響をみると、 $\mathrm{AE}$ 剂 $\mathrm{Al}$ を用いたフライアッシュコンクリートでは、 傾胴型ミキサーを用いたものの耐久性指数が特に低くなっているが、 それ以外のものでは明確な傾向は認められない。

アジテートによる影響を見ると、全てのコンクリートでアジテー 卜後に空気量が減少し、フライアッシュコンクリートは普通コンク リートよりも空気量の減少が大きい傾向があり、 $\mathrm{AE}$ 剂 $\mathrm{A} 1$ を用いた フライアッシュコンクリートの空気量の減少が $\mathrm{AE}$ 凨 $\mathrm{M}$ を用いたも のに比べて大きくなっている。また、 $\mathrm{AE}$ 剂 $\mathrm{A} 1$ を用いたフライアッ シュコンクリートは $\mathrm{AE}$ 剂 $\mathrm{M}$ を用いたものに比べて耐久性指数が低 く、アジテートによる空気量の低下とともに耐久性指数も大きく低 下していることがわかる。一方、 $\mathrm{AE}$ 剂 $\mathrm{M}$ を用いたフライアッシュ コンクリートは、アジテートにより空気量が低下しているにもかか わらず耐久性指数の低下が小さくなっている。

気泡間隔係数之耐久性指数の関係を図 11 に、硬化後の空気量亡気 泡間隔係数の関係を図 12 に示す。なお、これらの図にはアジテート 後および静置後のコンクリートも含まれている。ややばらつきはあ るものの、気泡間隔係数が大きくなると耐久性指数が低下している こと、気泡間䧎係数が同等でもフライアッシュコンクリートの耐久 性指数は低めであることがわかる。また、図 12 から、 $\mathrm{AE}$ 剂 $\mathrm{A} 1$ を 用いたフライアッシュコンクリートは、空気量が多いものでも気泡 間隔係数が比較的大きく、 $\mathrm{AE}$ 郕 $\mathrm{M}$ を用いたコンクリートは、空気 量が少なくても気泡間隔係数が小さいことがわかる。前述のように フライアッシュコンクリートの空気量の経時変化が大きいが、 AE 剂 M を用いると、アジテートによって空気量が低下しても気泡間隔係 数が小さく、耐久性指数が大きくなっているものと考えられる。

\section{（3）耐凍害性に及ぼす養生の影響}

養生が圧縮強度と耐久性指数に及ぼす影響を図 13 に示す。なお、 凍結融解試験結果と圧縮強度には空気量の影響が大きいため、FA 無 の試験体では、空気量と強度・耐久性指数の関係から補間により空
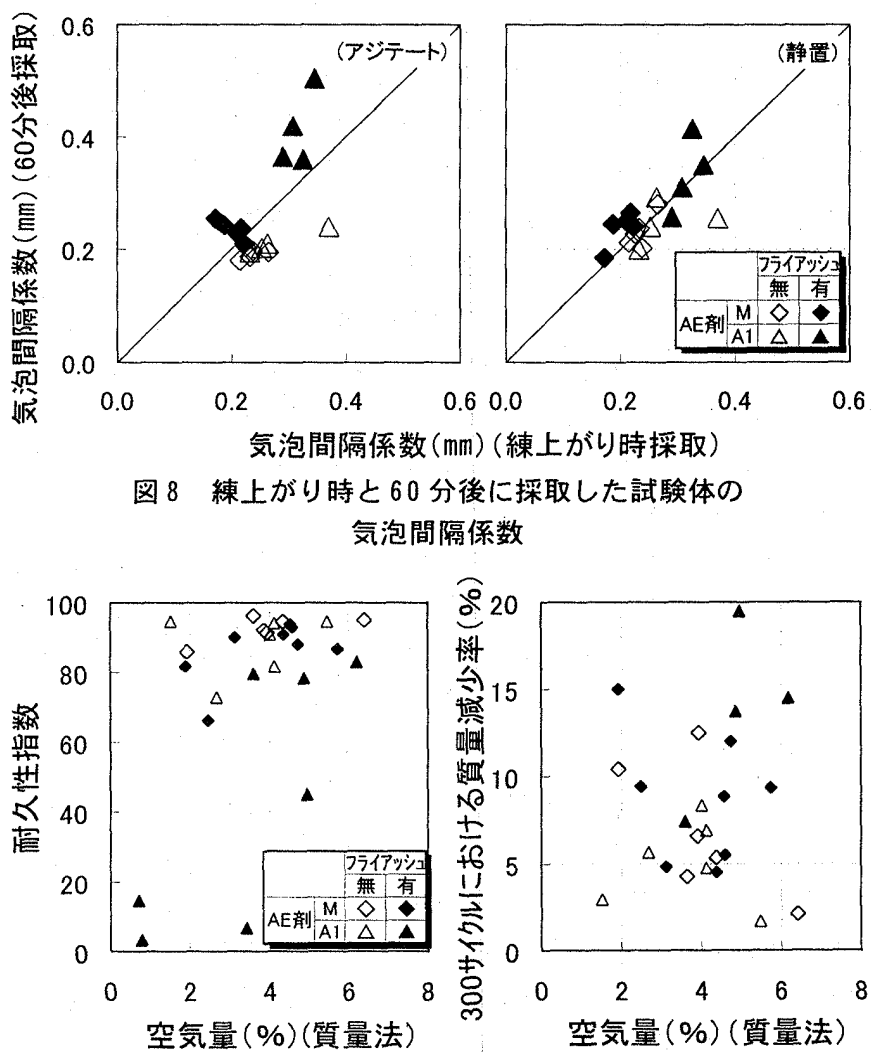

気泡間隔係数 $(\mathrm{mm})$ (練上がり時採取) と60 分後に採取した試験体の 泡間隔係数

図 9 空気量と耐久性指数・質量減少率の関係

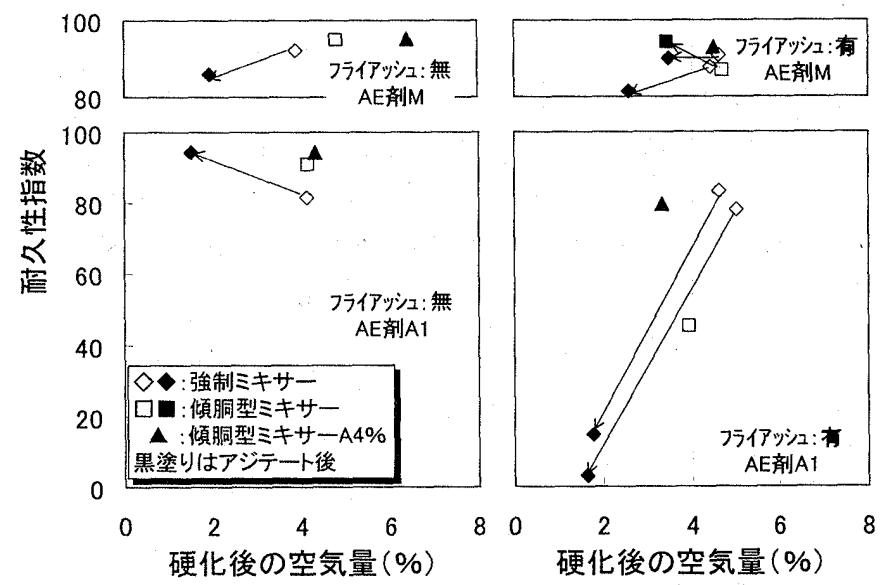

図 10 ミキサー理類・アジテートが空気量と耐久指数に 及ぼす影響

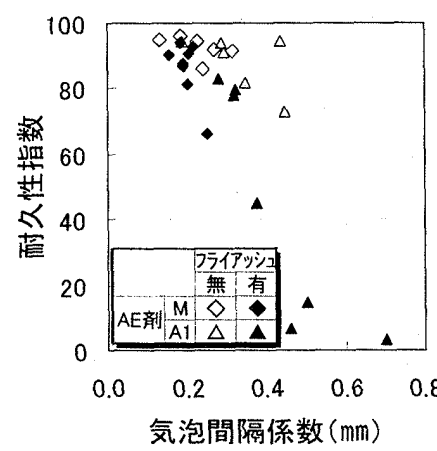

図 11 気泡間隔係数之 耐久性指数

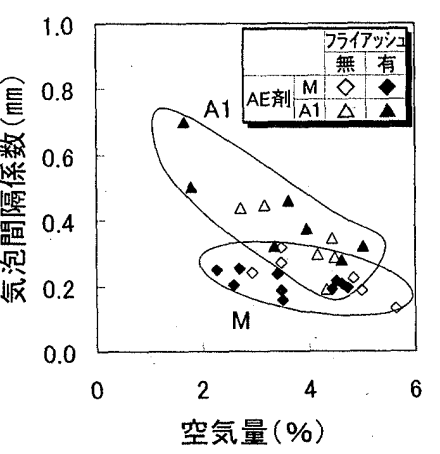

図 12 硬化後の空気量と 気泡間隔係数 
気量が FA 有と同一のときの值に補正したものを用いている。凍結 融解試験開始材齢を 2 週とした場合、空気量が確保されたフライ アッシュコンクリートの耐久性指数はある程度高い值を示すもの の、普通コンクリートより低い值となっている。フライアッシュコ ンクリートの養生期間を 4 週とすると、圧縮強度は普通コンクリー トと同等となり、耐久性指数も同等となることがわかる。

美生期間が圧縮強度と質量減少率に及ぼす影響を図 14 に示す。 この図においても空気量と強度・質量減少率の関係から、補間によ り空気量が同一のときの值に補正したものを用いている。フライ アッシュコンクリートは、養生期間を 4 週とすることにより質量減 少率が 2 週に比べて小さくなっているのがわかる。

以上から、フライアッシュコンクリートは材踰 2 週で凍結融解試 験を行うと、フライアッシュを使用しないコンクリートに比ベ、養 生が不十分なために耐凍害性が低く評価されるものと考えられる。

5. まとめ

（1）フライアッシュの基礎性状をとらえ、等価セメント量に換算し て AE 剂量を推定する方法は、フライアッシュコンクリートの空気 量管理方法として適用の可能性があることが示された。

(2)フライアッシュの有無・混練条件・AE 剤種別は、コンクリート の空気連行性・空気量の経時変化・気泡組織に影響を与える。特に、 普通コンクリートはアジテートすることにより気泡間隔係数がやや 小さくなる傾向があるが、フライアッシュを混入したものではアジ テートによって空気量が減少するとともに気泡間隔係数が大きくな る傾向がある。

（3）フライアッシュコンクリートは、AE 剤を選定することにより気 泡間隔係数を小さくでき、かつアジテートによる空気量の低下に対 しても気泡間隔係数を小さく保つことができる。

（4）フライアッシュコンクリートは、材齢 2 週で凍結融解試験を開 始すると、養生が不十分なために耐凍害性が低く評価される。

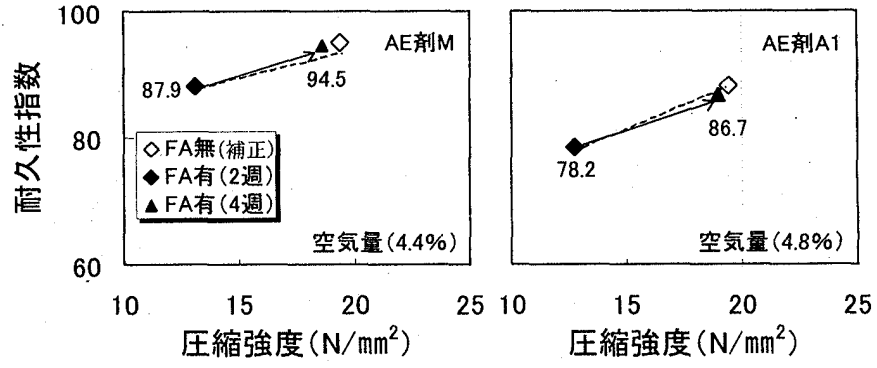

図 13 養生が圧縮強度と耐久性指数に及ぼす影響

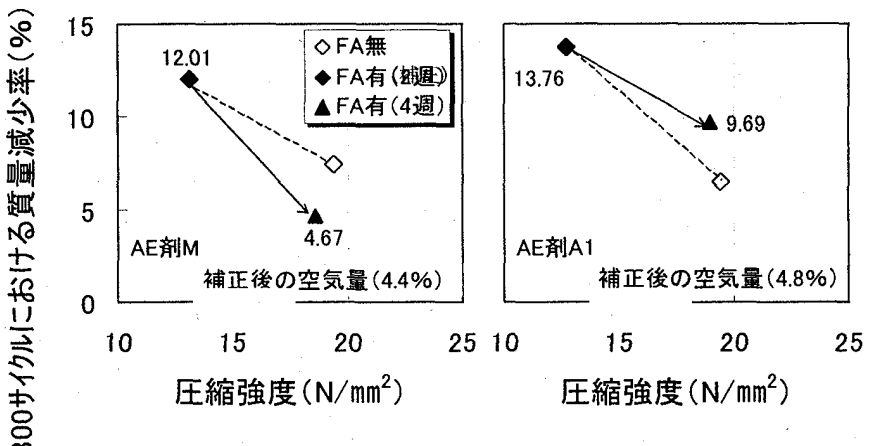

図 14 養生が圧縮強度と質量減少率に及ぼす影響

\section{謝辞}

本研究の実施にあたり、ご協力いただいた当特の大学院生の坂恵整介君ならびに 当洔の卒論生の馬場雄一郎君に謝意を表します。

\section{参考文献}

1）長滰重義他、7ラ仍ッシュを混和したコンクリートの酎凍害性評価、セメント技術年 報、Vol.41、pp371〜375、1987

2）千歩 修他、フライアッシュコンクリートの空気量·気泡組織の経時変化と耐 凍害性、日本建築学会大会学術暴演梗概集 (関東)、pp $47 \sim 48 、 1997$

3）須藤由美子他、フライアッシュコンクリートのAE剂使用量算定方法の提案、 日本建築学会粗造系論文集、No.510、pp1〜6、1998.8

4）日本建築学会、フライアッシュコンクリートを使用するコンクリートの調合 設計・施工指針(案)・同解祱、1999.2 